\title{
Factors Affecting Women's Satisfaction During Labor Experience
}

\author{
${ }^{1}$ Prof. Safaa Abdel Raouf Hashem, ${ }^{2}$ Dr. Manar Fathy Heeba, ${ }^{3}$ Hala Mohammed Elgazzar \\ ${ }^{I}$ Prof. of Gynecological and Obstetric nursing, Faculty of Nursing-Ain Shams University, \\ ${ }^{2}$ Lecturer of Maternity, Gynecological and Obstetrical Nursing, Faculty of Nursing, Port \\ Said University. ${ }^{3}$ B.Sc, of Nursing, Mansoura University,
}

\begin{abstract}
Background: Childbirth satisfaction provides a feedback for the evaluation of nursing care and determination of the quality of nursing services. The aim of the current study was to assess factors affecting women's satisfaction during labor experience. A descriptive design was adopted in the current study. Setting: the study was conducted at labor ward in Mansoura city hospitals during the period from June, 2014 to December, 2014. Sample of 214 laboring women were recruited to participate in this study. Two tools were used for data collection; demographic data assessment tool, and women's satisfaction assessment tool. The results of the current study revealed that, the higher percentage of studied women were satisfied with general environment, cleanliness, communication and physical care while most of them were dissatisfied with psychological care and involving in decision making. Conclusion: There are several factors that affecting women's satisfaction with services during labor. The main factors are general environment, cleanliness, communication, physical care, continuity of care, psychological care and involving in decision making. Recommendations: Continuity of nursing care, emotional support and involvement in decision making for laboring women should be enhanced by healthcare providers to improve their satisfaction.
\end{abstract}

Key word: childbirth, satisfaction, factors, labor experience 


\section{INTRODUCTION}

Satisfaction is defined as fulfillment of one's expectations. Most researchers seem to agree that satisfaction involves both what the patient expects and what the healthcare environment delivers (Stevens, 2012). Intrapartum satisfaction is a broad, multi-faceted concept that includes women's experience of labor, birth and immediate postpartum. Satisfaction in this context is often about giving birth in a manner that suits the needs of each woman (Bertucci et al., 2012). Childbirth itself has a substantial physical and emotional impact. For these reasons, the assessment of women's satisfaction with their perceptions of childbirth is important to women themselves, due to the implication for the health and well-being of the mother, newborn, and the mother-infant relationship. It is also important to the health care providers in offering the best preparation to childbearing women (Kuo, Lin \&Hsu, 2010).

Maternal satisfaction with care during labor and the postpartum period is influenced by multiple factors such as care givers and client's interactions. The positive attitudes led to satisfaction and encouraged future usage of the hospital (Dzomeku, 2011). Birth satisfaction is achieved when the women's perception of the quality of care and services that they receive in delivery care setting has been positive, satisfying, and meet their expectation (The Health Boards Executive, 2012).

In Egypt, the large maternity governmental hospitals are facing serious challenges in providing care that is of consistently high quality in a rapidly changing and uncertain environment. Health care providers perceived load as the leading challenge to quality care. The caseload observed included obstetric emergencies, high risk cases, caesarean sections, in addition to normal deliveries. Their main concern is how to manage the cases with minimum loss. Furthermore, limited facilities, the current nursing shortage, nurse job dissatisfaction and inequality of distributed cases over the day are causing staff overloading at peak intake (Cherine, 2004) . This surrounding environment minimizing the chance to stop for minutes and think about the woman's expectations and how to be enjoyed with her birth experience. Questions about specific aspects of patients' needs and preferences may be the key ingredients to ensure optimal birthing experiences in term of modifying the performance. Thus the 
aim of the present study was to determine women's preferences and needs during labor.

\section{Significance of the study:}

There isn't enough researches concerning with the factors affecting women's satisfaction level during that affecting women's satisfaction level with maternity services at Mansoura hospitals with regard to the issues raised. This research will help the health care providers to understand how the patients view the services that are rendered to them. Also, the study was motivated by various encounters with patients who expressed their dissatisfaction about the services that they had received in the maternal ward. They were specifically dissatisfied with the information they were given, their level of participation in the decision making process and psychological care during labor.

\section{AIM OF STUDY:}

The aim of the present study is to determine factors affecting women's satisfaction during labor experience.

\section{Research Objectives:}

- Determine the important factors that may effect on woman's satisfaction.

- Assess the level of women's satisfaction with labor care.

\section{SUBJECTS AND METHODS:}

\section{Technical Design:}

-Research design: Descriptive research design was adopted in this study.

-Setting: The study was conducted at the delivery ward in Mansoura City Hospitals namely; General Hospital, El-Dawly Hospital, and Talkha Hospital.

\section{Sampling design:}

Target Population: The population of this study was women attend to the previous mentioned hospitals in delivery ward. Sample size: 214 women. 
Sampling technique: A purposive sampling technique was followed for all normal laboring women of chosen setting depending on the selection criteria until the sample size was completed.

\section{Inclusion criteria:}

Gestational age from 37 weeks to 42 weeks.

Aged: from 20-35 years old

* Free from medical \& gynecological health problems.

Agree to participate in the study.

All women with different parity.

\section{Tools of data Collection:-}

Three main tools were used in the study for data collection.

Tool (1): Basic data structured interview schedule: it consists of two parts:-

Part (1): To collect necessary data about socio demographic data.

Part (2): History of current pregnancy and previous deliveries.

Tool (2): Women's satisfaction assessment tool: it was used to assess the level of women's satisfaction about nursing care offered during labor it consists of seven categories as follows; general environment, cleanliness, communication, physical care, continuity of care, psychological care and involving in decision making.

Scoring system: every statement was given a score; satisfied was scored (3), uncertain was scored (2) and dissatisfied was scored (1). Range of response from 38114. Total women satisfaction score will conducted according to total women response on the sheet. If the women total score from 77- 114 was considered satisfied. If the women total score at the level of 76 so their stratification will be judged as uncertain. If the total women scored 75 or less was considered dissatisfied.

\section{II- Administrative Design and Ethical Considerations:}

Before starting any step in the current study, an official letter was addressed from the dean of the Faculty of Nursing, Port-Said University to the directors of the identified study settings, requesting their cooperation and permission. Purpose of the study was explained to each woman and a oral consent was obtained. 


\section{III-Operational design:}

Preparatory phase: The researcher reviewed the available local \& international related literature of current study, from using text books, articles, and scientific magazines. The data collection tools were prepared. Then, needed modifications were done.

Content validity: It was ascertained by a Jury consisting of five experts in nursing fields, to make sure that the measuring instrument looks as though it is measuring what purports to measure. Changes were done according to the experts opinions. This phase was carried out in a period of two weeks.

Testing reliability: Crombach alpha coefficient was calculated to assess the reliability of the developed tools through its internal consistency.

Pilot study: Pilot study was carried out on $10.0 \%$ (20 women) of the total sample. The purposes of the pilot study were to test the applicability and clarify the feasibility of the study tools and it served to estimate the time needed to complete the tools. Certain modification of the tools was done. Subjects included in the pilot study were excluded from the study subjects.

The field work: The researcher was identified she for each participant, the purpose of the study was explained and oral consent was obtained. Collection of data covered a period of seven months from the beginning of June, 2014 to the end of September; 2014. The researcher attained the study settings three days per week (one day for each hospital) from 9 am to $3 \mathrm{pm}$. At the delivery ward women were interviewed individually and the researcher collected mother's socio-demographic data and obstetrical history. Confidentiality and anonymity of their responses was ensured. Then the researcher filled the women's satisfaction assessment tool from the mother. Mothers were interviewed within 10-15 minutes for explaining the purpose of the study and filling the sheet.

VI- Statistical analysis: Data was collected, presented in tabular form. Percentages were calculated for quantitative data using the statistical Package for social Sciences 
(SPSS) for statistical analysis. The Fisher's exact test, Quite square test were used in this study to analysis and interpretation the data.

\section{RESULTS:}

Table (1): reveals that, more than one third of studied women (37.4\%) aged between 26-30 years old, while (26.2\%) aged between 31-35 years old. Regarding educational level more than half of women $(53.3 \%)$ read and write, whereas only (12.1\%) have secondary level of education. Furthermore, the majority of studied women (87.9\%) were housewives. Also, more than half of studied women (57\%) resided in rural area. As for monthly income, in $73.8 \%$ of them, it was between 500- 1000 pounds.

Table (2): shows that, $38.3 \%$ of studied women were gravida two, while $(28.1 \%)$ of them were gravida one. In relation to parity less than half of them $(40.2 \%)$ were para one, and $(26.2 \%)$ were para two or more. As regards number of abortions, the majority of women $(79.4 \%)$ didn't aborted, while $0.9 \%$ aborted two or more. Additionally, more than half of studied women (55.1\%) in gestational age 39- 40 weeks, and only (17.8\%) of them were 41-42 weeks gestational age.

Table (3): showed that, the higher percentage of studied women were satisfied with general environment, cleanliness, communication and physical care $76.6 \%, 75.7 \%$, $68.2 \%$ and $60.7 \%$ respectively. While, $56.1 \% \& 16.8 \%$ of them were respond uncertain and dissatisfied respectively with continuity of care. Moreover, $37.4 \%$ and $25.2 \%$ of women were dissatisfied and uncertain respectively with psychological care. Regarding involving in decision making, all of studied sample were dissatisfied.

Table (4): reveals that, there are statistically significant differences between age of studied women and the level of satisfaction, while there are non-statistically significant differences between level of education, occupation or family income with women's satisfaction level.

Table (5): reveals that, there was a highly statistically significance between women's satisfaction level and number of parity $\left(\mathrm{X} 2=10.778 \& \mathrm{P}\right.$-value $\left.=0.005^{*}\right)$, while there are non-statistically significant differences between the number of gravida, number of abortion and gestational age with women's satisfaction level $(\mathrm{p}>0.05)$. 
Table (1): Frequency and distribution of women according to their sociodemographic characteristics $(\mathrm{N}=214)$

\begin{tabular}{|c|c|c|c|c|c|c|c|c|c|}
\hline \multirow[t]{2}{*}{ General characteristics } & \multicolumn{2}{|c|}{$\begin{array}{l}\text { General } \\
(\mathrm{n}=58)\end{array}$} & \multicolumn{2}{|c|}{$\begin{array}{c}\text { El-Dawly } \\
(n=68)\end{array}$} & \multicolumn{2}{|c|}{$\begin{array}{l}\text { Talkha } \\
(\mathbf{n}=88)\end{array}$} & \multicolumn{2}{|c|}{$\begin{array}{c}\text { Total } \\
(n=214)\end{array}$} & \multirow[t]{2}{*}{ Significance } \\
\hline & No & $\%$ & No & $\%$ & No & $\%$ & & & \\
\hline Age (year) & & & & & & & & & \\
\hline $20-25$ & 20 & 34.5 & 24 & 35.3 & 34 & 38.6 & 78 & 36.4 & $X^{2}=1.626$ \\
\hline $26-30$ & 26 & 44.8 & 22 & 32.4 & 32 & 36.4 & 80 & 37.4 & $\mathrm{P}=0.80$ \\
\hline $31-35$ & 12 & 20.7 & 22 & 32.4 & 22 & 25.0 & 56 & 26.2 & \\
\hline Educational level & & & & & & & & & \\
\hline Illiterate & 20 & 34.5 & 26 & 38.2 & 28 & 31.8 & 74 & 34.6 & $X^{2}=4.282$ \\
\hline Read and write & 30 & 51.7 & 40 & 58.8 & 44 & 50.0 & 114 & 53.3 & $P=0.36$ \\
\hline Secondary & 8 & 13.8 & 2 & 2.9 & 16 & 18.2 & 26 & 12.1 & \\
\hline Occupation & & & & & & & & & \\
\hline Housewife & 54 & 93.1 & 58 & 85.3 & 76 & 86.4 & 188 & 87.9 & $X^{2}=1.049$ \\
\hline Occupied & 4 & 6.9 & 10 & 14.7 & 12 & 13.6 & 26 & 12.1 & $\mathrm{P}=0.59$ \\
\hline Residence & & & & & & & & & \\
\hline Rural & 26 & 44.8 & 42 & 61.8 & 54 & 61.4 & 122 & 57.0 & $X^{2}=2.410$ \\
\hline Urban & 32 & 55.2 & 26 & 38.2 & 34 & 38.6 & 92 & 43.0 & $\mathrm{P}=0.30$ \\
\hline Monthly income & & & & & & & & & \\
\hline More than 1000(enough) & 8 & 13.8 & 10 & 14.7 & 6 & 6.8 & 24 & 11.2 & $X^{2}=1.823$ \\
\hline 500-1000(slightly enough) & 40 & 69.1 & 50 & 73.5 & 68 & 77.3 & 158 & 73.8 & $P=0.76$ \\
\hline Less than 500(not enough) & 10 & 17.2 & 8 & 11.8 & 14 & 15.9 & 32 & 15.0 & \\
\hline
\end{tabular}

Table (2): Frequency and distribution of women according to their reproductive history $(\mathrm{N}=\mathbf{2 1 4})$.

\begin{tabular}{|c|c|c|c|c|c|c|c|c|c|}
\hline \multirow[t]{2}{*}{ Reproductive history } & \multicolumn{2}{|c|}{$\begin{array}{l}\text { General } \\
(\mathrm{n}=58)\end{array}$} & \multicolumn{2}{|c|}{$\begin{array}{c}\text { El-Dawly } \\
(n=68)\end{array}$} & \multicolumn{2}{|c|}{$\begin{array}{l}\text { Talkha } \\
(n=88)\end{array}$} & \multicolumn{2}{|c|}{$\begin{array}{c}\text { Total } \\
(n=214)\end{array}$} & \multirow[t]{2}{*}{ Significance } \\
\hline & No & $\%$ & No & $\%$ & No & $\%$ & & & \\
\hline Gravidity & & & & & & & & & \multirow{4}{*}{$\begin{aligned} X^{2} & =1.718 \\
P & =0.79\end{aligned}$} \\
\hline One & 14 & 24.1 & 24 & 35.3 & 22 & 25.0 & 60 & 28.1 & \\
\hline Two & 22 & 37.9 & 26 & 38.2 & 34 & 38.6 & 82 & 38.3 & \\
\hline Three or more & 22 & 37.9 & 18 & 26.5 & 32 & 36.4 & 72 & 33.6 & \\
\hline \multicolumn{10}{|l|}{ Parity } \\
\hline Zero & 16 & 27.6 & 26 & 38.2 & 30 & 34.1 & 72 & 33.6 & \multirow{3}{*}{$\begin{array}{c}\mathrm{X}^{2}=0.942 \\
\mathrm{P}=0.92\end{array}$} \\
\hline One & 26 & 44.8 & 24 & 35.3 & 36 & 40.9 & 86 & 40.2 & \\
\hline Two or more & 16 & 27.6 & 18 & 26.5 & 22 & 25.0 & 56 & 26.2 & \\
\hline \multicolumn{10}{|l|}{ No. previous abortion } \\
\hline One & 38 & 65.1 & 58 & 85.3 & 74 & 84.1 & 170 & 79.4 & \multirow{3}{*}{$\begin{aligned} X^{2} & =6.891 \\
P & =0.14\end{aligned}$} \\
\hline \multirow{2}{*}{ Two or more } & 20 & 34.5 & 10 & 14.7 & 12 & 13.6 & 42 & 19.6 & \\
\hline & 0 & 0.0 & 0 & 0.0 & 2 & 2.3 & 2 & 0.9 & \\
\hline Gestational age & & & & & & & & & \multirow{4}{*}{$\begin{aligned} \mathrm{X}^{2} & =2.840 \\
\mathrm{P} & =0.58\end{aligned}$} \\
\hline $37-38$ & 22 & 37.9 & 16 & 23.5 & 20 & 22.7 & 58 & 27.1 & \\
\hline $39-40$ & 26 & 44.8 & 38 & 55.9 & 54 & 61.4 & 118 & 55.1 & \\
\hline $41-42$ & 10 & 17.2 & 14 & 20.6 & 14 & 15.9 & 38 & 17.8 & \\
\hline
\end{tabular}


Table (3): Frequency and distribution of studied women according to factors affecting on satisfaction with labor nursing care in three sample setting $(\mathrm{N}=214)$.

\begin{tabular}{|c|c|c|}
\hline \multirow[t]{2}{*}{ Satisfaction items } & \multicolumn{2}{|c|}{$\begin{array}{c}\text { Total } \\
(n=214)\end{array}$} \\
\hline & No & $\%$ \\
\hline $\begin{array}{l}\text { General environment } \\
\text { Satisfied } \\
\text { Uncertain } \\
\text { Dissatisfied }\end{array}$ & $\begin{array}{c}164 \\
16 \\
34\end{array}$ & $\begin{array}{c}76.6 \\
7.5 \\
15.9\end{array}$ \\
\hline $\begin{array}{l}\text { Cleanliness } \\
\text { Satisfied } \\
\text { Uncertain } \\
\text { Dissatisfied }\end{array}$ & $\begin{array}{c}162 \\
18 \\
34\end{array}$ & $\begin{array}{c}75.7 \\
8.4 \\
15.9\end{array}$ \\
\hline $\begin{array}{l}\text { Communication } \\
\text { Satisfied } \\
\text { Uncertain } \\
\text { Dissatisfied }\end{array}$ & $\begin{array}{c}146 \\
20 \\
48\end{array}$ & $\begin{array}{c}\mathbf{6 8 . 2} \\
9.3 \\
22.4\end{array}$ \\
\hline $\begin{array}{l}\text { Physical care } \\
\text { Satisfied } \\
\text { Uncertain } \\
\text { Dissatisfied }\end{array}$ & $\begin{array}{c}130 \\
38 \\
46\end{array}$ & $\begin{array}{l}\mathbf{6 0 . 7} \\
17.8 \\
21.5\end{array}$ \\
\hline $\begin{array}{l}\text { Continuity of care } \\
\text { Satisfied } \\
\text { Uncertain } \\
\text { Dissatisfied }\end{array}$ & $\begin{array}{c}58 \\
120 \\
36\end{array}$ & $\begin{array}{l}27.1 \\
\mathbf{5 6 . 1} \\
16.8\end{array}$ \\
\hline $\begin{array}{l}\text { Psychological care } \\
\text { Satisfied } \\
\text { Uncertain } \\
\text { Dissatisfied }\end{array}$ & $\begin{array}{l}80 \\
54 \\
80\end{array}$ & $\begin{array}{l}37.4 \\
25.2 \\
37.4\end{array}$ \\
\hline $\begin{array}{l}\text { Involving in decision making } \\
\text { Satisfied } \\
\text { Uncertain } \\
\text { Dissatisfied }\end{array}$ & $\begin{array}{c}0 \\
0 \\
214\end{array}$ & $\begin{array}{c}0.0 \\
0.0 \\
\mathbf{1 0 0 . 0}\end{array}$ \\
\hline
\end{tabular}


Table (4): Relation between women's satisfaction level and Socio-demographic characteristics of the studied women from different hospitals

\begin{tabular}{|c|c|c|c|c|c|c|c|}
\hline \multirow{3}{*}{ Items } & \multicolumn{6}{|c|}{$\begin{array}{l}\text { Satisfaction score } \\
\qquad(\mathrm{n}=214)\end{array}$} & \multirow{3}{*}{ Significance } \\
\hline & \multicolumn{2}{|c|}{$\begin{array}{l}\text { Dissatisfactory } \\
\text { (less than 76) } \\
(n=64)\end{array}$} & \multicolumn{2}{|c|}{$\begin{array}{l}\text { Uncertain } \\
\qquad \begin{array}{l}(=76) \\
(n=2)\end{array}\end{array}$} & \multicolumn{2}{|c|}{$\begin{array}{l}\text { Satisfactory } \\
\begin{array}{c}(\mathbf{7 7 - 1 1 4}) \\
(\mathrm{n}=148)\end{array}\end{array}$} & \\
\hline & No. & $\%$ & & & No. & $\%$ & \\
\hline \multicolumn{7}{|l|}{ Age (years) } & \multirow{4}{*}{$\begin{array}{c}X^{2}=10.518 \\
P=0.005 *\end{array}$} \\
\hline $20-$ & 14 & 6.5 & 0 & 0.0 & 64 & 29.9 & \\
\hline $25-$ & 26 & 12.1 & 2 & 0.9 & 52 & 24.3 & \\
\hline $30-\leq 35$ & 24 & 11.2 & 0 & 0.0 & 32 & 15 & \\
\hline \multicolumn{7}{|l|}{ Level of education } & \multirow{4}{*}{$\begin{array}{l}X^{2}=1.110 \\
P=0.574\end{array}$} \\
\hline Illiterate & 22 & 10.3 & 0 & 0.0 & 52 & 24.3 & \\
\hline Read and write & 36 & 16.8 & 2 & 0.9 & 78 & 36.4 & \\
\hline $\begin{array}{l}\text { Secondary or its } \\
\text { equivalent }\end{array}$ & 6 & 2.8 & 0 & 0.0 & 20 & 9.3 & \\
\hline \multicolumn{7}{|l|}{ Occupation } & \multirow{3}{*}{$\begin{array}{l}X^{2}=0.806 \\
P=0.369\end{array}$} \\
\hline Housewife & 56 & 26.2 & 0 & 0.0 & 132 & 61.7 & \\
\hline Working & 8 & 3.7 & 2 & 0.9 & 16 & 7.5 & \\
\hline \multicolumn{7}{|l|}{ Family income } & \multirow{4}{*}{$\begin{array}{l}\mathrm{X}^{2}=2.974 \\
\mathrm{P}=0.226\end{array}$} \\
\hline More than enough & 4 & 1.9 & 0 & 0.0 & 20 & 9.3 & \\
\hline Just enough & 48 & 22.4 & 2 & 0.9 & 108 & 50.5 & \\
\hline Less than enough & 12 & 5.6 & 0 & 0.0 & 20 & 9.3 & \\
\hline
\end{tabular}

\section{$\mathrm{X}^{2}$ : Chi-Square test *significant at $\mathbf{P} \leq \mathbf{0 . 0 5}$}

Table (5): Relation between women's satisfaction level and Obstetric history of the studied women from different hospitals.

\begin{tabular}{|c|c|c|c|c|c|c|c|}
\hline & \multicolumn{6}{|c|}{ Satisfaction score } & \\
\hline & \multirow{3}{*}{\multicolumn{2}{|c|}{$\begin{array}{c}\text { Dissatisfactory } \\
\text { (less than 76) } \\
(n=64)\end{array}$}} & \multirow{3}{*}{\multicolumn{2}{|c|}{$\begin{array}{l}\text { Uncertain } \\
\qquad \begin{array}{l}(=76) \\
(n=2)\end{array}\end{array}$}} & \multirow{3}{*}{\multicolumn{2}{|c|}{$\begin{array}{c}\text { Satisfactory } \\
\begin{array}{c}(77-114) \\
(n=148)\end{array}\end{array}$}} & \\
\hline \multirow[t]{3}{*}{ Items } & & & & & & & \multirow[t]{3}{*}{ Significance } \\
\hline & & & & & & & \\
\hline & No. & $\%$ & No. & $\%$ & No. & $\%$ & \\
\hline \multicolumn{7}{|l|}{ Gravidity } & \multirow{3}{*}{$\begin{array}{l}X^{2}=3.867 \\
P=0.145\end{array}$} \\
\hline One & 12 & 5.6 & 2 & 0.9 & 46 & 21.5 & \\
\hline Two & 24 & 11.2 & 0 & 0.0 & 58 & 27.1 & \\
\hline
\end{tabular}




\begin{tabular}{|c|c|c|c|c|c|c|c|}
\hline Three or more & 28 & 13.1 & 0 & 0.0 & 44 & 20.6 & \\
\hline Parity & & & & & & & \multirow{4}{*}{$\begin{array}{l}X^{2}=10.778 \\
P=0.005^{*}\end{array}$} \\
\hline One & 12 & 5.6 & 2 & 0.9 & 58 & 27.1 & \\
\hline Two & 26 & 12.1 & 0 & 0.0 & 60 & 28.0 & \\
\hline Three or more & 26 & 12.1 & 0 & 0.0 & 30 & 14.0 & \\
\hline Abortion & & & & & & & \multirow{3}{*}{$\begin{array}{c}X^{2}=0.331 \\
P=0.565\end{array}$} \\
\hline None & 54 & 25.2 & 0 & 0.0 & 116 & 54.2 & \\
\hline One or more & 10 & 4.7 & 2 & 0.9 & 32 & 15.0 & \\
\hline Gestational ag & & & & & & & \multirow{4}{*}{$\begin{array}{c}\mathrm{X}^{2}=2.225 \\
\mathrm{P}=0.329\end{array}$} \\
\hline $37-38$ & 18 & 8.4 & 0 & 0.0 & 40 & 18.7 & \\
\hline $39-40$ & 38 & 17.7 & 2 & 0.9 & 78 & 36.4 & \\
\hline $41-42$ & 8 & 3.7 & 0 & 0.0 & 30 & 14.0 & \\
\hline
\end{tabular}

\section{DISCUSSION:}

As regards the results of women's satisfaction level, the results showed that there are several factors that affect women's satisfaction level. These factors are general environment, cleanliness, communication, physical care, involving in decision making and psychological care. There were varying degrees of satisfaction with various services provided in the labor ward in three hospitals, ranging from dissatisfaction with involving in decision making and psychological care to satisfaction with general environment, cleanliness, communication and physical care. The variability in the women's responses to different aspects of intrapartum care suggests that women pay attention to details of the quality of care they are offered.

Regarding women's satisfaction level in relation to physical environment and cleanliness, the findings of the present study revealed that, the majority of women were satisfied with physical environment and cleanliness in three sample setting. The current study finding is in agreement with Lumadi, and Buch (2011) in South Africa, who found that, $72.1 \%$ were satisfied with the general cleanliness of the wards. Also, the present study finding is agreed with Khumalo, (2013) \& Kavitha et al. (2014), who found that, the satisfaction levels among women was high with general environment. It may be due to the high level of following the infection control practices and the fact that the cleaners are supervised by the nurses in charge 
of the wards who check the environment regularly for cleanliness and could be emphasizing that cleaners do their duties.

Sheehy, (2011) reported that, the physical environment in which care is provided is also believed to impact on woman health and safety, effectiveness of care, and morale of staff. In most developed western countries, attempts have been made to make the labor and birth environment less clinical and more homelike. Satisfaction with the physical environment is a significant predictor of women's overall satisfaction and positive experience in labor and birth (Foureur et al., 2010).

Concerning women's satisfaction with communication behaviors of nursing staff, the current study findings showed that, slightly more than two thirds of studied sample $(68.2 \%)$ was satisfied with nurses' communication. This result agreed with a study of Ashraf, Rahman\&Khan (2012) in Pakistan who show that $79 \%$ of women were satisfied with the communication factor. In this respect, the study of Shafiei, et al. (2012) in Australia showed that the nature of interaction with nurses was mentioned by all women as particularly important in their satisfaction or dissatisfaction with the care they received during childbirth.

The current study findings were disagreed with Mohammed, Shaban, Homer, and Creedy (2014), who found in Jordan that, only $13.0 \%$ of women were satisfied with interpersonal care during intrapartum care. These differences in findings may be due to the difference in areas of the studies and the difference in population and their expectations and experiences.

Concerning physical care, the current study revealed that the higher percentage of studied women $(60.7 \%)$ was satisfied.Satisfaction with the physical care is a significant predictor of women's overall satisfaction and positive experience in labor and birth (Foureur et al., 2010). The current study supported with Ashraf, Rahman\&Khan (2012) in Pakistan who found that, $61 \%$ of women were satisfied with the physical care, while $39 \%$ only were dissatisfied.

Physical care in labor has been shown to improve its outcome as stated by Shennan (2004). Factors related to structure of care also made women feel more 
comfortable and in control during labor and birth as indicated in the study of Hildings\& Thomas (2007) in Sweden. On the other hand, the current study finding is inconsistent with the study of Small, et al. (2002) in Australia who manifested that $64 \%$ of women perceived as not caring during childbirth, and this significantly reduced their overall satisfaction with their care.

Regarding satisfaction with continuity of care, the study findings showed that, $56.1 \% \& 16.8 \%$ of women were respond uncertain and dissatisfied respectively with continuity of care. These results may be due to the nurse left the woman for a long period of time particularly during first and fourth stage. Midwives' relational continuity of care has important implications for promoting normal birth and a positive experience for women. The present study finding is disagree with the study of Williams, et al. (2010) in Australia, which strongly indicated that the presence of a known midwife during labor helped women feel supported, confident and well informed.

Also, the study of Mbeinkong (2010) in Burea showed that $93 \%$ of women reported attendance by the nurse at regular intervals. Generally, the Cochrane review of Hodnett et al. (2009) revealed that continuous supportive care in labor provides maternal and neonatal benefits without any known risks.

In relation to satisfaction with psychological care, the current study findings revealed that, the levels of satisfaction were satisfied (37.4\%), uncertain (25.2\%), dissatisfied (37.4\%). From the point of view of the researcher, it may be due to poor emotional support during intrapartum period from nursing staff. Emotional support in labor has been shown to improve its outcome and is probably the best way to avoid problems as emphasized by Shennan, (2004). In addition, when the study of Waldenstrom, et al. (2006) in Sweden taking all aspects of intrapartum care into account; those related to emotional dimensions of care seemed to influence women's overall satisfaction. And they clarified that dissatisfaction with emotional aspects of care during childbirth was a stronger risk factor than dissatisfaction with physical care. 
The results of the current study are in accordance with Lumadi, \& Buch (2011) who noticed that, $53.2 \%$ of mothers were satisfied with the support, kindness and psychological care of staff during labor and delivery. Also, Kavitha et al. (2014)in Eritrea who assess mother's satisfaction with intrapartum nursing care among postnatal mothers. He mentioned that, the majority of women (74.0\%) were highly satisfied with the emotional and psychological support.

As regards to involving in decision making, the results of the current study illustrated that, all of women were dissatisfied. Involvement in decisions about labor procedures can affect women's perceptions of satisfaction (Hatamleh et al., 2013).

This result is disagree with the recent research of Lumadi, and Buch (2011) in South Africa, who mentioned that, $32.9 \%$ of mothers were satisfied with the way in which they had been involved in decision making related to their care. In fact, women's participation in decision making during labor promotes their feelings of control, coping and support (Hauck, et al. 2007). In addition, the study of Waldenstrom, et al. (2006) displayed that lack of opportunity to participate in decision making, increased the risk of not being satisfied with overall intrapartum care.

\section{CONCLUSION:}

Based on study findings, it can be concluded that: there are several factors that affecting women satisfaction as general environment, cleanliness, communication, physical care, continuity of care, psychological care and involvement in decision making.

- The higher percentages of studied women were satisfied with general environment, cleanliness, communication and physical care. While most of them were dissatisfied with psychological care, continuity of care and involvement in decision making.

- There was a statistically significant difference between age and number of parity of studied women and their level of satisfaction. 


\section{RECOMMENDATIONS:}

Based on the results of the present study, the following recommendations were suggested:

The quality of intrapartum nursing care must improve through:

- Increase the number of staff nurses.

- Nurses should have refresher courses about the quality care of intrapartum women to increase their knowledge about proper care.

- Implementation of regular checks on the intrapartal nursing care, make nurses have a sense of duty consciousness.

- Continuity of nursing care, emotional support and involvement in decision making for laboring women should be enhanced to improve their satisfaction.

\section{Recommendations related to further studies:}

- Further studies must identify factors responsible for the low quality of nursing care offered during labor.

- Developing educational programs concerning quality of intrapartum nursing care which related to health teaching, emotional labor support, and the women's right to participate in decision making which effects on their overall satisfaction.

\section{REFERENCES:}

Ashraf, M., Ashraf, F., Rahman, A. \& Khan, R. (2012): Assessing women's satisfaction level with maternity services: Evidence from Pakistan. International Journal of collaborative Research on Internal Medicine \& Public Health. Vol. 4 No. 11.

Bertucci, V., Boffo, M., Mannarini, S., Serena, A., Saccardi, C., Cosmi, E., et al. (2012): Assessing the perception of the childbirth experience in Italian women: A contribution to the adaptation of the childbirth perception questionnaire. Midwifery $2012 ; 28: 265-74$. 
Cherine, M. K., Khalil, N., Hassanein, H., Sholkamy, M., Breebaart, A. and Elnoury, A. (2004): Management of the third stage of labor in an Egyptian teaching hospital. International Journal of Gynaecology \& Obstetrics, 87(1): 54-58.

Dzomeku MV. (2011): Maternal satisfaction with care during labour: A case study of the Mampong-Ashanti district hospital maternity unit in Ghana. Int J Nurs Midwifery. 2011;3:30

Foureur, M., Davis, D., Fenwick, J., Leap, N., Iedema, R.., Forbes, I. \& Homer, C.S. (2010): The relationship between birth unit design and safe, satisfying birth: Developing a hypothetical model. Midwifery 26(3):520-525.

Hatamleh, R., Sinclair, M., Kernohan, G. \& Bunting, B. (2013): Birth memories of Jordanian women: findings from qualitative data. J. Res. Nurs. 18(3):235-244.

Hauck, Y., Fenwick, J., Downie, J. \& Butt, J. (2007): The influence of childbirth expectations on Western Australian women 's perceptions of their birth experience . Midwifery 2007;23:235-47.

Hildings, I. \& Thomas, J. (2007): Women's perspectives on maternity services in Sweden : processes . problems, and solution . Journal of Midwifery \& Women's Health 2007 March \April ; 52 (2) : 126-33.

Hodnett, E., Gates, S., Hofmeyr, G. \& Sakala, C. (2009): Continuous support for women during childbirth. Cochrane Database of Systematic reviews Library 4:2-68.

Kavitha, P., Parasath, R.A., Solomon, H., Tsegay, L., Tsegay, W., \&Teklit, Y. (2014): Mother's satisfaction with intrapartum nursing care among postnatal mothers in orotta national referral maternity hospital, asmara, Eritrea. International Hournal of Allied Medical Science and Clinical Research; 2(3): 249-254.

Khumalo, N. 2013: Factors that influence patients' satisfaction with peri-partum care in Germiston Hospital maternity unit. Faculty of health science, Universty of the Witwatersrand Johannesburge. 
Kuo, S., Lin, K. \& Hsu, C. (2010): Evaluation of the effects of a birth plan on Taiwanese women's childbirth experiences, control and expectations fulfillment: a randomized controlled trial . International Journal of Nursing Studies2010;47: 806-14 .

Lumadi, T.G., \&Buch, E. (2011): Patients' satisfaction with midwifery services at a regional hospital and its referring clinics in the Limpopo Province of South Africa.Africa Journal of Nursing and Midwifery; 13 (2): 14-28.

Mbeinkong Ch. (2010): Patient satisfaction with intra-partum and postpartum nursing car: the case of Buea regional hospital. published bachelor dissertation in Nursing Science, Faculty of Health Sciences, Department of Nursing, University of Buea , Republic of Cameroon . July 2010.

Mohammed, K., Shaban, I., Homer, C., \&Creedy, D. (2014): Women's satisfaction with hospital based intrapartum care: a Jordanian study.

Shafiei T, Small Rh. \& McLachlan H. (2012): Women's views and experiences of maternity care: A study of immigrant Afghan women in Melbourne, Australia. Midwifery 2012: 28:198-203

Sheehy, A., Foureur, M., Catling-Paull, C., Homer, C. (2011): Examining the content validity of the birthing unit design spatial evaluation tool within a woman-centered framework . J. Midwifery Women's Health 56:494-502.

Shennan, A. (2004): Management of labor. Anesthesia \& Intensive Care Medidine. July 1; 5 (7): $226-27$.

Small, R.h., Yelland, J., Brown, S. \& Liamputtong, P. (2002): Women's views about care during labor and birth : An Australian study of Vietnamese, Turkish, and Filipino women . Birth 2002 December 4;29: 266-77.

Stevens, J. (2012): Perceived control and maternal satisfaction with childbirth: a measure development study.J. Psychosom Obst Gynecol 2012;33: 15-24.

The Health Boards Executive, (2012): Measurement of patient satisfaction guidelines: health strategy implementation project. 2003. Available at URL: http:||lwww.lenus.ielhselhandle\10147\43559. Retrieved : 18 December 2012. 
Waldenstrom, U., Ann, R. \& Hildingsson, I. (2006): Intrapartum and postpartum care in Sweden : women 's opinions and risk factors for not being satisfied Acta Obstetricia et Gynecologica $2006 ; 85: 551-60$.

Williams, k., Lago, l., Lainchbury, A., \& Eagar, $k$. (2010): Mothers' views of caseload midwifery and the value of continuity of care at an Australian regional hospital. Midwifery 2010; 26:615021.

\section{العوامل المؤثرة على رضا السيدات عن تجربة الولادة}

'أ.د/ صفاء عبد الرؤف هاثم ، ‘د/ منار فتحى هيبة ، هالة محمد محمد الجزار

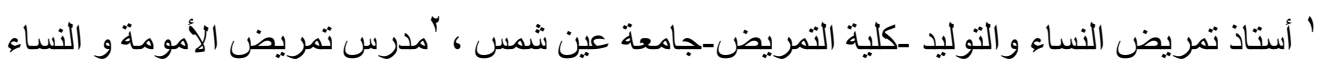

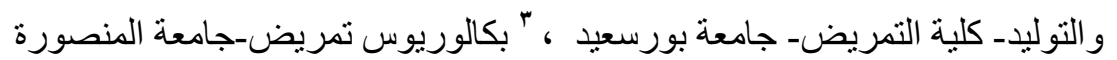

\section{الخلاصة}

إن رضا السيدات أثناء الولادة الطبيعية يقدم مرجعية أو خلفية تساعد فى تقييم الرعاية التمريضية وتحديد مستوى جودة الخدمات الصحية. تهدف هذه الدراسة الوصفية إلى تقييم العو امل المؤثرة على رضا السيدات أثناء الو لادة، و أجريت هذه الدر اسة في قسم الو لادة في المستشفيات التابعة لوز ارة الصحة بمدينة المنصورة علي عينة

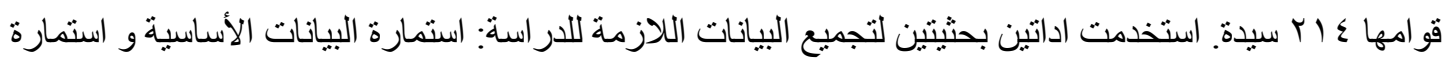

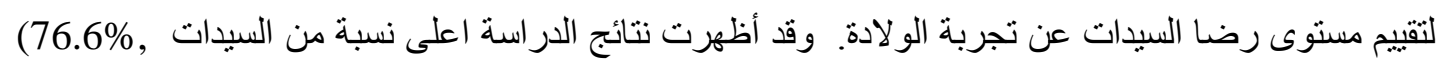

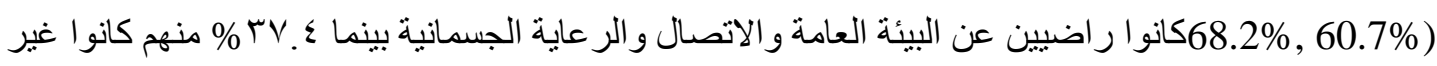
راضبين عن الرعاية النفسية بينما كلهم كانو ا غير راضيبين عن عدم اشتتر اكهم في اتخاذ القرار. وقد استنتجت الدراسة الحالية أن هناك علاقة بين عمر السيدة وعدد مرات الولادة ومستوى رضا السيدات عن تجربة الو لادة،. وبناءا علبه أوصت هذه الدراسة بانه يجب الوضع فى الاعتبار استمر ارية الرعاية والمساندة العاطفية و ايضا اشرك السيدات فى اتخاذ القرار وذلك لتحسين مستوى رضا السيدات عن جودة الرعاية التمريضية أثناء 